In making an inventory of these forms and norms, Christoff paid particular attention to obshchina, sobornost', and the nascent purity of religious beliefs and behavior. 'The Slavophiles, as Christoff saw them, accorded primacy to faith over reason. His articles on Khomiakov and Kireevskii in The Encyclopedia of Philosophy summed up the main principles of the Slavophile world outlook.

In addition to his work on Slavophilism, Christoff published two general studies on the intellectual fermentation in Russia during the first four decades of the nineteenth century: The Third Heart: Some Intellectual-Ideological Currents in Russia: $1800-1830(1970)$ and "La renaissance culturelle russe des années 1830 et 1840" (in Histoire de la littérature russe, 1996). These publications concentrated on the ideological turbulence in Russia caused by the increasing contact with the west. Conditions leading to a rising conflict between Slavophilism and westernism provided the central topic of these studies.

Christoff's historical studies are based not only on a careful and competent reading of primary and secondary sources but also on a profound awareness of the currents of thought carrying broader philosophical and sociological messages.

Alexander Vucinicil Berkeley, California January 1998

\title{
Donald Carlisle, 1935-1997
}

Donald Carlisle, associate professor of political science at Boston College and an associate and fellow at the former Harvard University Russian Research Center (now known as the Davis Center for Russian Studies), died on Monday, 8 December 1997 at 2:30 in the afternoon. After fighting cancer for about a year, he finally succumbed to a heart attack. Many students and faculty throughout the world, especially those in Russian area studies within the fields of political science and Uzbek studies, mourn his passing. At Boston College where Carlisle taught for almost thirty years, he was an energetic, lively lecturer and a very popular teacher, though he was known locally as "Killer Carlisle" because of his tough grading.

Carlisle rose from working-class conditions in New Haven, Connecticut, where he was born on 11 September 1935. He received his undergraduate degree summa cum laude from Brown University in 1958 and his Ph.D. from Harvard University in 1962.

Carlisle taught at the University of Wisconsin at Madison from 1962 until 1967, at the University of Toronto from 1967 to 1968, and at Boston College from 1968 until his death. He had been the associate director of the Russian and East European Center at Boston College since 1968, and the executive director of the Balkan Studies Project at Boston College since 1994. In 1984 he was visiting professor at Columbia University, and from 1985 to 1986 he served as president of the New England Slavic Association. At Boston College he regularly taught courses on Soviet politics, art, and civilization, and he team-taught courses on the Balkans with historian Raymond McNally. In addition, he developed expertise in the study of Central Asia, in general, and Uzbekistan, in particular. The United Nations Development Programme (UNDP) selected Carlisle to be a consultant and member of the UNDP delegation to Tashkent and Uzbekistan (27 October to 11 November 1992), a member of the UNDP delegation to Dushambe, Tajikistan (19 September 1993), analyst of the Management School Program in Kyrgyzstan for two weeks, and a member of a two-month mission to all five Central Asian countries to plan a regional conference (August-September 1994). He was invited to Uzbekistan by the president, Islam Karimov, for consultations in July 1995, and he was recently honored at the Harvard University Faculty Club for his work on Uzbek studies. He read and spoke Russian, German, and Uzbek.

Carlisle's interest ranged beyond those of the ordinary political scientist; he de- 
veloped an interest in the Trubetskoi equestrian statue of Alexander III and in the Cathedral of Christ the Savior in Moscow, which Stalin had had destroyed and which was recently reconstructed and reopened; Carlisle was invited to attend these opening ceremonies.

His principal articles included "Uzbekistan and Uzbeks," in Z. Katz, R. Rogers, and F. Harned, eds., Handbook of Major Soviet Nationalities (1975); "Modernization, Generations, and the Uzbek Intelligentsia," in P. Cocks, R. Daniels, and N. Heer, eds., The Dynamics of Soviet Politics (1976); "Power and Policy in Uzbekistan: From Stalin to Gorbachev," in William Fierman, ed., Soviet Central Asia: The Failed Transformation (1991); "Soviet Uzbekistan: State and Nation in Historical Perspective," in Beatrice F. Manz, ed., Central Asia in Historical Perspective (1994); "Islam Karimov and Uzbekistan: Back to the Future?" in T. J. Colton and R. C. Tucker, eds., Patterns in Post-Soviet Leadership (1995). Carlisle's book (co-authored with Leonid Levitin) entitled Islam Karimov-President of New Uzbekistan (1995) was published in English, Russian, German, and Uzbek editions. Shortly before his death, Carlisle had completed the manuscript of his planned pièce de résistance entitled Uzbekistan under Russian Rule, which had already been accepted for publication.

RAYMOND T. MCNALIY

Boston College

December 1997

\section{George Basilus Tokmakoff, 1928-1997}

George Basilus Tokmakoff, professor emeritus of Russian history at California State University, Sacramento, passed away on 15 November 1997 at the age of sixty-nine. Born in Tientsin, China, of Russian immigrant parents, Tokmakoff emigrated to the United States in 1947. He earned his undergraduate degrees at the University of Washington and his doctorate at the University of London's School of Slavonic and East European Studies. Tokmakoff wrote P. A. Stolypin and the Third Duma: An Appraisal of the Three Major Issues (1981), in addition to several articles and book reviews. He was a frequent contributor to international panels dealing with Stolypin, the agrarian issue, and the reign of Nicholas II. In 1991, Tokmakoff retired from California State University, Sacramento, but he was actively involved in a definitive work on the reign of Nicholas II at his death. He will be sorely missed by thousands of students; friends across the world; his children, Andrei and Larisa; and his granddaughter, Lena.

RichaRd D. Hughrs

California State University, Sacramento December 1997 